\title{
http://www.emeraldinsight.com/doi/full/10.1108/IJPDLM-10-
}

$\underline{\text { 2012-0325 }}$

\section{Exploring the Use of 25 Leading Business Practices in Emerging Market Supply Chains}

\section{Structured Abstract:}

Purpose - In the global economy, managers of organizations are constantly innovating with their use of available supply chain management tools. Some tools, like strategic planning and customer segmentation, have gained strong global acceptance while others are less universal. In this study, we focus our contribution on the organizational factors that predict firm usage of supply chain management tools in two Eastern Europe countries, Slovenia and Croatia, while also comparing them to the global use of similar management tools.

Design/methodology/approach - This research provides an empirical analysis of supply chain management tool usage from a survey of 155 firms in Slovenia and 185 firms in Croatia while also comparing these findings to results from a global Bain \& Company survey.

Findings - The 25 most commonly used supply chain management tools in our Eastern European survey were found to be relatively similar to those used across Europe and North America. However, further analysis of five selected tools reveals important differences. Evidence is found to support that particular organizational factors have a significant influence on supply chain management tool usage, of specific importance is the education level of the organization manager.

Research limitations/implications - The research study is limited to the research question, selective literature review, and survey sample from Eastern Europe.

Practical implications - As firms assess their supply chain management tool usage, the findings presented here might serve as a guide to improve their understanding of why organization managers employ particular tools more consistently than others.

Originality/value - The findings are useful for business practice in understanding the influences of organizational factors on supply chain management tool usage. Also, the research is original as previous management literature has not provided a similar approach to researching management tools and their usage.

Keywords: Management, management tools, supply chain management tools, organizational factors

Article Classification: Research Paper 


\section{Introduction}

In the competitive global environment, organizations can only achieve long term survival through continual improvement (Jennings, 2005; Hartley, 2007; Daft, 2009; Martin, 2009). Therefore, organizations are constantly innovating in their use of management tools. Management tools may include a variety of techniques firms utilize in managing their organization. Tools such as strategic planning, benchmarking, and total quality management are among the most commonly used in many firms around the world (Rigby and Bilodeau, 2007) and represent some of the leading business practices in firm supply chains. However, the utilization of modern management tools come from a long history in the content-related development of management as a scientific discipline which includes many distinct phases, i.e. Classical, Humanistic, Systems, Contingency, Post-modernistic, and the Scientific Values (Galbraith, 2002; Hatch, 2006; Linstead et al., 2009; Lafley and Johnson, 2010; Mullins, 2010). In each phase, researchers developed numerous explanations in reference to the meaning of an abstract or generic management idea (Lock, 1992; Cole, 2004; Armstrong, 2006; Daft, 2007; Certo and Certo, 2009).

Specifically, this study aims to review how organizations use management tools for the betterment of their supply chains. Supply chain management involves the integration of different internal functional areas with parties outside the firm. Through supply chain management, suppliers, customers, and third-party providers share information in an effort to make the channel more efficient and thus competitive (Ellram and Cooper, 1990). Supply chain management tools are the means by which the organization pursues the integration requirements of supply chain management and the adoption of supply chain management-enhancing tools have a positive impact on firm value and investors (Filbeck et al., 2005). Even firms engaging in minimum levels 
of supply chain management realize the importance of exchanging quality information at superior speeds with channel members (Fawcett and Magnan 2002). Supply chain management tools may assist firms in pursuit of information integration through such tools as strategic planning, knowledge management, strategic alliances, etc.

While some global aspects of management tool usage have been examined (Rigby and Bilodeau, 2007; Rigby and Bilodeau, 2009; Rigby, 2011), they are limited to main geographic regions, excluding new members of the European Union. Thus, new European countries, such as Slovenia and Croatia, formerly a part of Yugoslavia, are excluded from those surveys. Our study investigates the state of supply chain management tool usage in new European countries - i.e. former transition economies moving from government-planned economy to free market economy, which has previously not been attempted in the literature. Slovenia joined the European Union in 2004 and Croatia will join on July 1st, 2013.

The term management is subject to many interpretations (Chandler, 1996; Black, 1997; Cooper and Argyris, 1998; Gove, 2002; Wren, 2004; Daft, 2005; Schermerhorn, 2009) with numerous concepts attributed to the meaning of management and the work of managers. In modern theory and the practice of management, complexity is ever increasing which generates new dilemmas for researchers around understanding the need for, and benefits received from the use of management tools. (Etzioni, 1997; Schermerhorn and Chappell, 2004; Hitt et al., 2008; Certo and Certo, 2009; Potocan and Mulej, 2009).

A comparison of all available supply chain management tools is an almost impossible undertaking. As such, the research presented here is limited to the usage of a selected 25 supply chain management tools as outlined in the yearly Bain \& Company tools and trends report (Rigby and Bilodeau, 2007; Rigby and Bilodeau, 2009; Rigby, 2011). These 25 tools were chosen as 
they represent the most utilized tools throughout the world. A comparison of global trends against those in specific countries or regions may assist researchers in understanding how these emerging market supply chains are different from those around the globe as they move from developing to a more fully developed economic status. As international firms increase their presence in these emerging markets, previous literature has focused on various issues such as sustainability (Richey et al., 2005). However, a comparison of the tools successfully used in other countries should be meaningful in achieving sustainability or other goals such as profitability. This study includes a literature review of supply chain management tools to assist in addressing the influence of selected organizational factors on the usage of supply chain management tools in Eastern European organizations. Later, a comprehensive review regarding the impact of five selected organizational factors on the usage of supply chain management tools is conducted with important organizational factors revealed. In terms of practical implications, this study reveals the state of use of supply chain management tools as well as the influence of selected organizational factors on tool use in Slovenia and Croatia. 


\section{Literature review of supply chain management tools and theory}

\subsection{Supply chain management tool consideration}

Due to the numerous supply chain management tools discussed in the current literature (Wren, 2004; Armstrong, 2006; Potocan and Kuralt, 2007; Daft, 2009; Lafley and Johnson, 2010) the researchers found it impractical to form a direct comparison of most and/or all known tools.

Indeed, previous research has discussed the obstacles to comparing supply chain management tools (Cooper and Argyris, 1998; Rigby, 2001; Schermerhorn and Chappell, 2004; Mullins, 2010). These include:

- Differences in the considered starting-points and basics for the development of tools (e.g., level of knowledge, development of the environment, and the level of communicational and informational technology);

- Differences in contextual and methodological characteristics between single tools (e.g., intention, aim of orientation, and considered factors); and

- Differences in the demand and conditions for the possible use of the tools (e.g., results of the use of the same tools in various conditions).

Despite the difficulties involved with comparing supply chain management tools, managers are continually faced with the need to evaluate their application of these tools.

Additionally, previous research has enumerated the benefits that managers could receive if they were able to compare those tools (Pascale, 1990; Lock, 1992; Daft, 2009; Buchanan and Huczynski, 2010). 
Research regarding contingency theory and post-modernistic theory over the past 20 years has investigated supply chain management tools on the basis of their use (Cole, 2004; Crainer, 2004; Hartley, 2007; Linstead et al., 2009; Potocan and Nedelko, 2010). The application of an indirect approach to the discussion enables a clearer understanding of supply chain management tool usage and provides a possible starting point for a detailed study. Thus, the decision-making process should benefit from: 1) the direct comparison of single tools; and 2) the comparison of the use of the tools in different and/or comparable circumstances, conditions and work environments (Potocan and Mulej, 2009; Potocan and Nedelko, 2010).

A literature review of supply chain management from Power (2005) called for further empirical analysis to determine the techniques that are most successful in managing the supply chain. With empirical studies of supply chain issues consuming $54 \%$ of supply chain research (Burgess et al., 2006) it is evident that connecting the work of academics to practitioners through empirical work is prevalent. Empirical studies are also valuable in providing benchmarking metrics, which are useful for managers when evaluating the success of their management tool usage in the supply chain (Slone et al., 2007).

\subsection{Factors determining usage of supply chain management tools}

Previous research has explored some of the organizational factors that influence usage of supply chain management tools (Etzioni, 1997; Cole, 2004; Crainer, 2004; Armstrong, 2006; Quick and Nelson, 2009; Buchanan and Huczynski, 2010; Mullins, 2010). Further research in management and organization theory has uncovered important factors that influence organizational stakeholder behaviors. In accordance with relevant literature (Cole, 2004; Armstrong, 2006; Daft, 2007; 
Linstead et al., 2009; Buchanan and Huczynski, 2010), organizational factors can be described to include: environmental factors (Etzioni, 1997; Cole, 2004; Daft, 2005; Armstrong, 2006; Certo and Certo, 2009; Buchanan and Huczynski, 2010), general factors (Cooper and Argyris, 1998; Cole, 2004; Crainer, 2004; McAuley et al., 2007; Potocan and Kuralt, 2007; Daft, 2009; Mullins, 2010), and specific factors (Etzioni, 1997; Cooper and Argyris, 1998; Daft, 2007; Hitt et al., 2008; Daft, 2009; Buchanan and Huczynski, 2010). All organizational factors in this study were considered on one of three levels: individual, group or organization (Etzioni, 1997; Cooper and Argyris, 1998; Daft, 2007; Hitt et al., 2008; Daft, 2009; Buchanan and Huczynski, 2010). A model of factors that influence organization behaviors is presented as Figure 1.

\section{Insert Figure 1 Here}

\subsection{Theory}

A resource based view (RBV) of the firm is useful to rationalize the organizational employment of supply chain management tools. According to the tenets of RBV, organizations will acquire resources that are valuable, rare, inimitable and non-substitutable in their effort to obtain an advantage over their competitors (Barney, 1991). RBV is viewed as arguably the dominant theory utilized in strategic management research to explain the varied performance outcomes among organizations (Barney et al., 2001). Resources may include assets, capabilities, organizational processes, firm attributes, information, knowledge, etc. that improve organizational efficiency and effectiveness (Daft, 1983). Supply chain management tools are part of these firm resources. Some resources are tangible, such as software, and others intangible, 
such as the concepts behind knowledge management or mission and vision statements. Regardless of the asset type, organizations will attempt to leverage their use of supply chain management tools, including the bundling of multiple tools, to provide them with a sustainable competitive advantage.

\subsection{Global supply chain management tool usage}

The Bain Research Group and their exploration into the use of supply chain management tools is often mentioned in the literature (Rigby and Bilodeau, 2007; Rigby and Bilodeau, 2009; Rigby, 2011) as they have completed comprehensive studies over the last 19 years in Latin America, Asia, Europe and North America. The focal Bain Research Group study included here discusses 25 supply chain management tools and will present a starting point for our research. In conjunction with the use of data provided from the Bain Research Group, a survey was developed to inquire about manager use and satisfaction with a large set of supply chain management tools. The survey was established to: 1) determine the basic characteristics of the leading supply chain management tools, 2) establish the reasons for choosing that tool, and 3) collect data that is comparable with publicly accessible information regarding the use of supply chain management tools in organizations.

Results regarding supply chain management tool usage in this study are based on responses from 340 Eastern European organizations. We compare our data with the 25 leading supply chain management tools identified by Bain's worldwide study in 2006 (Rigby and Bilodeau, 2007) which includes regional information from around the globe. Additionally, 
further analysis of the top 10 most commonly used tools among our Eastern European organizations has been compared to the 10 most commonly used management tools in North America, Europe, and Globally (Rigby and Bilodeau, 2007).

Further analysis was conducted to explore the organizational factors that predict and influence firm use of supply chain management tools. Figure 2 illustrates the use of supply chain management tools in Slovenian, Croatian, and European organizations.

Insert Figure 2 Here

In general, a noticeable pattern of tool usage can be found in figure 2, indicating that the use of supply chain management tools in studied organizations is similar in many ways to that of organizations across Europe with supply chains extending into the realm of business performance, strategy and corporate capabilities. However, important differences are deserving of further investigation. The top ten most commonly used supply chain management tools in our Eastern European sample of organizations was then compare with the top ten most commonly used tools in the selected areas from a worldwide study - i.e., Global, North America, and Europe (Rigby and Bilodeau, 2007), see table 1.

Insert Table 1 Here

Interestingly, the most commonly used tool globally, strategic planning, is eighth on the list in our Eastern European sample. As seen in table 1, the priorities given to specific supply 
chain management tools in Croatia and Slovenia differ from each other and from other regions around the world. Managers work in a global marketplace, often operating in multiple countries. A deeper understanding of the organizational factors that influence tool usage will benefit managers.

\subsection{Supply chain management tool usage in Croatia and Slovenia}

Previous investigations by Chandler (1996), Cooper and Argyris (1998), Crainer (2004), and Mullins (2010), and other current literature (Cole, 2004; Armstrong, 2006; Linstead et al., 2009; Buchanan and Huczynski, 2010; Potocan and Mulej, 2009; Potocan and Nedelko, 2010; Potocan and Dabic, 2011), lead us to develop the following research question around the use of supply chain management tools in Eastern Europe.

\section{Research Question:}

How useful are the organizational factors of education, employee position, organization size, and working years in understanding firm utilization of the top five supply chain management tools?

To investigate the link between organizations and their use of supply chain management tools, the organizational factors most frequently considered and empirically examined in previous research were chosen for investigation: education, position, organizational size, and working years (Etzioni, 1997; Armstrong, 2006; Mullins, 2010; Buchanan and Huczynski, 2010). Regarding the perceived differences in the usage of supply chain management tools in Slovenia and Croatia, we turn our attention to examining the impact of the selected factors (employee education, employee position, employee working years, and organizational size) on the usage of 
single supply chain management tools. Five specific single supply chain management tools were selected for inclusion in this study based on two considerations: (1) the tool is used at a different frequency in Slovenia and Croatia, and (2) the tool is among the top 5 most commonly used supply chain management tools in at least one country. The following tools met both of the above requirements: (1) outsourcing, (2) knowledge management, (3) total quality management, (4) mission and vision statements, and (5) customer segmentation.

A brief explanation of each of the five tools selected is provided here with the methodology of the analysis following afterward. Outsourcing is "the operation of shifting a transaction previously governed internally to an external supplier through a long-term contract, and involving the transfer of staff to the vendor ([Lacity and Hirschheim, 1993b] and [Barthélemy, 2001])" (Quélin and Duhamel, 2003 p. 648). Knowledge management is the organizational storage or sharing of accumulated information regarding customers, products and processes (Bollinger and Smith 2001). Total quality management is driven by top management but part of an organization-wide philosophy of performance improvement which stresses that all employees play an important role in the firm (Chorn 1991). Additionally, previous research on total quality management found it to be important to firm supply chain and logistics performance (Zineldin 2004; Brah and Lim 2006). Mission and vision statements are public documentation that provide clarity and a concrete structure of ideas which managers can use in their administration of the firm (Lipton 1996). Customer Segmentation includes division of customers according to buying behaviors or service needs thus allowing firms to design their supply chains to meet the specific requirements of individual segments (Barratt 2004).

\section{$3 \quad$ Methodology}




\subsection{Methods and instruments}

We propose that usage of management tools can be approximated by a linear combination of selected organizational factors, i.e. employee education, employee position, organizational size, and employee working years. The model does not account for all variance and thus an error variable is also included, (Er1). See figure 3 below for a path diagram of the analysis which was used to test the relationships between organizational factors and management tools.

\section{Insert Figure 3 Here}

\subsection{Data and sample characteristics}

We created a survey to assess the use of specific supply chain management tools based on those tools included in Bain's worldwide survey (Rigby, Bilodeau, 2007; 2009; Rigby, 2011). These survey items were combined with other items to survey supply chain management tools usage by Slovenian and Croatian employees. The final survey consists of three parts: Part $1-$ questions about usage, knowledge, satisfaction and desire to become familiar with 40 management tools included in the survey; Part 2 - general questions about management tools, like one's need to use management tools in the organization, influence of management tools on improvements/innovation in organizations, etc; and Part 3 - demographic information about respondents and organizations.

Surveys were administered in 2010 to Slovenian and Croatian organizations as part of our study of Eastern European supply chain management tools. Altogether, we sent 1500 
questionnaires to organizations via post; 750 in Croatia and 750 in Slovenia. We received 223 completed questionnaires from Croatia and 210 from Slovenia. Questionnaires that were missing data, more than $5 \%$, and that contained obvious patterns of answering that were not in line with the postulated questions were removed prior to analysis. This resulted in 185 Croatian and 155 Slovenian questionnaires remaining valid for analysis. The response rate is $24.7 \%$ for Croatia and $20.7 \%$ for Slovenia; the overall response rate was $22.7 \%$. To enable measuring single management tool usage, respondents rated each tool using a Likert-type scale ranging from "I know and use tool" (1) to "I don't know and don't use tool" (3). Demographic information such as education level was also measured using scale items where respondents had options from "primary school” to "Ph.D.", for position from "specialists" to "CEO”, for organization size from "micro" to "large" and for working years employees put the number of years they had been working in organization.

The participating organizations in Croatia and Slovenia provide a representative sample of many organization types (i.e., regional coverage, the basic-activity structure of organizations in the country, complementary sample according to the industry-based structure of the national economy). Additionally, all organizations in the sample were determined to be involved in some type of supply chain management activity.

Responses to the organization factors of employee position and organizational size deviated from the expected representative samples for both Croatia and Slovenia. Although managers often do not comprise $50 \%$ of a firm's employees, in the survey conducted here managers provided the majority of the responses, see table 2. However, this was central to the study as managers are crucially important in determining the usage of supply chain management tools in their organizations. 
Insert Table 2 Here

In relation to organization size, despite that more than $95 \%$ of organizations have less than 10 employees; organizations of this size comprised the smallest portion of our sample at $13.5 \%$, see table 3. We can merely conclude that the structure of organizations in our samples is quite different from what was expect since small and medium enterprise represent a great majority of organizations in both countries. But again, the rationale for focusing especially on large and medium organizations is based on the presumption that supply chain management tools are more frequently used or at least known in larger organizations, e.g., more potential users, costly implementation of tools, suitability of supply chain management tool for many users, interactive nature of tools, etc. However, regardless of size, we presupposed that supply chain management tools in both countries were used to some extent in smaller and larger organizations.

Insert Table 3 Here

Despite some deviations, we conclude that the obtained data are adequate for analyzing supply chain management tools in organizations regarding both content and methodology. The basic demographic characteristics from the survey respondents are presented in Table 4.

Insert Table 4 Here 
To assess normality, the Kolmogorov Smirnov test was applied which led to the conclusion that most of the variables do not markedly violate the assumptions of the normal distribution (Ho, 2006; Leech et al., 2008). Next, for testing the impact of the selected factors on the usage of supply chain management tools, a regression analysis was applied in SPSS, as outlined by Ho (2006). Usage of a single supply chain management tool is consequently predicted as a linear combination of the selected four observed independent variables. Missing values in each linear combination were handled using pairwise removal.

To assess non-response bias we utilized wave analysis as suggested by Rogelberg and Stanton (2007) and Armstrong and Overton (1977) as a method to evaluate potential bias. Responses returned before the deadline were compared with those returned after with no significant differences found among the five tools we analyze in this research. Based on these results, we conclude that non-response bias was not an issue. Means, standard deviations, and correlations for the variables of the interested are presented in Table 5.

Insert Table 5 Here

These findings suggest a deeper examination is warranted to understand the relationships between selected supply chain management tools and the factors that influence their usage. Collinearity statistics, calculated for every single regression analysis, as suggested by Ho (2006), 
between factors influencing usage of supply chain management tools and management tools usage reveals that multicollinearity is not a problem in this study.

\section{$4 \quad$ Research of management tools}

\subsection{Analysis and results of selected single management tools}

Results from our exploratory testing can be found for Slovenia in table 6 and Croatia in table 7. A discussion of the results is also offered below.

Insert Table 6 Here

Insert Table 7 Here

\section{Outsourcing}

Results reveal that organizational factors significantly influence the usage of outsourcing in Slovenian organizations, $\mathrm{F}(4,133)=11.037, \mathrm{p}<0.001$. Education is found to be significantly related to the usage of outsourcing as a supply chain management tool $(\beta=-.449 ; \mathrm{p}<0.001)$. Hence, we conclude that the higher the organizational members' education, the higher their usage of outsourcing. The impact of three remaining factors is not significant. The four predictor variables account for $24.9 \%$ of the variance in the usage of outsourcing in Slovenian organizations. 
For Croatia, results reveal that organizational factors significantly influence on usage of outsourcing in Croatian organizations, $\mathrm{F}(4,174)=2.896, \mathrm{p}<0.05$. Employee position $(\beta=-.265$; $\mathrm{p}<0.05)$ and organization size $(\beta=-.187 ; \mathrm{p}<0.05)$, are significantly related to outsourcing. Hence, organizational members in higher positions and in larger organizations will be more inclined to use outsourcing. The impact of education and working years is not significant. The four predictor variables account for $6.2 \%$ of the variance in the usage of outsourcing in Croatian organizations.

\section{Knowledge Management}

For Slovenia, results reveal that organizational factors significantly influence the usage of knowledge management in Slovenian organizations, $\mathrm{F}(4,130)=10.839$, $\mathrm{p}<0.001$. Education $(\beta=$ $-.444 ; p<0.001)$ and organizational size $(\beta=-.167 ; p<0.05)$, were found to be significantly related organizational factors regarding use of knowledge management. The effect of the other two variables is insignificant. Hence, we conclude that the higher the education of the organizational member and the larger the size of the organization, the more likely they are to use knowledge management. The four predictor variables account for $25.0 \%$ of the variance in the usage of knowledge management in Slovenian organizations.

For Croatia, results reveal that the joint effect of the four organizational factors on usage of knowledge management in Croatian organizations is not significant, $\mathrm{F}(4,173)=1.432$, $\mathrm{p}$ > 0.05 .

Turning to single factors, employee position is the only factor significantly associated with use of knowledge management $(\beta=-.180 ; p<0.05)$, with a total of $3.2 \%$ of the variance 
explained. Hence, we conclude that organizational members in higher positions in the firm are more likely to use knowledge management.

\section{Total Quality Management}

For Slovenia, results reveal that organizational factors significantly influence on usage of total quality management in Slovenian organizations, $\mathrm{F}(4,133)=18.016, \mathrm{p}<0.001$. Employee education $(\beta=-.482 ; \mathrm{p}<0.001)$, and position $(\beta=-.211 ; \mathrm{p}<0.05)$, are significantly associated with the use of total quality management. Hence, we conclude that the higher the education level and position of the employee, the higher his/her usage of total quality management. The impact of working years and organizational size is insignificant. The four predictor variables account for $35.1 \%$ of the variance in the usage of total quality management in Slovenian organizations.

None of the four organizational factors are found to be significantly related to the use of total quality management, among employees in Croatian organizations, $F(4,172)=1.026$, p > 0.05. In sum, they only account for $2.3 \%$ of the variance in the use of total quality management.

\section{Mission and Vision Statements}

Results reveal that organizational factors significantly influence the usage of mission and vision statements in Slovenian organizations, $F(4,133)=5.885, \mathrm{p}<0.001$. Education $(\beta=-.351 ; \mathrm{p}<$ 0.001), is the only significant organizational factor associated with the use of mission and vision statements in Slovenia. As such, higher employee education is associated with increased usage of mission and vision statements in Slovenia. Overall, the four predictor variables account for $15.0 \%$ of the variance in the usage of mission and vision statements in Slovenian organizations. 
Results reveal that organizational factors significantly influence usage of mission and vision statements in Croatian organizations, $\mathrm{F}(4,174)=3.303, \mathrm{p}<0.05$. Croatia is similar to Slovenia in that education $(\beta=-.161 ; \mathrm{p}<0.05)$, is a significant factor associated with the use of mission and vision statements. Additionally, organization size $(\beta=-.184 ; p<0.05)$, is also associated with the use of mission and vision statements. Thus, higher employee education and larger organizations are associated with increased usage of mission and vision statements in Croatia. The four predictor variables account for $7.1 \%$ of the variance in the usage of mission and vision statements in Croatian organizations.

\section{Customer Segmentation}

For Slovenia, results reveal that organizational factors significantly influence on usage of customer segmentation in Slovenian organizations, $F(4,132)=5.728, p<0.001$. Education $(\beta=-$ $.362 ; \mathrm{p}<0.001)$, is the only significant organizational factor associated with the usage of customer segmentation in Slovenian organizations. Thus, employees with higher education levels are more likely to use customer segmentation. The four predictor variables accounted for $14.8 \%$ of the variance in the usage of customer segmentation in Slovenian organizations.

None of the four organizational factors are significantly related to the use of customer segmentation among employees in Croatian organizations, $F(4,174)=1.424, p>0.05$. In sum, they only account for $3.2 \%$ of the variance in the use of customer segmentation. 


\subsection{Discussion}

On the bases of our findings are outlined above in table 6 and table 7, we came to the following conclusions regarding the use of the four selected organizational factors and their value in understanding the usage of supply chain management tools in Eastern European organizations. First, employee education is consistently found to be related to the use of supply chain management tools and provides a powerful understanding of the observed phenomenon in Slovenia. Secondly, employee position in the organization and organization size are found to have at least some, though limited, explanatory assistance in regard to supply chain management tool usage. Lastly, working years is surprisingly not a significant predictor of any supply chain management tool usage among Slovenian organizations.

Regarding Croatian organizations, the explanatory power of the selected organizational factors for the usage of supply chain management tools is weak. Employee education, employee position and organization size did have a relationship with tool usage, but overall the organizational factors analyzed explained much less variance in supply chain management tool usage in Croatia than in Slovenia, see table 6 and 7. In fact, total quality management and customer segmentation were found to have no significant connection to any of the four organizational factors.

\section{Conclusions}

This study was designed to provide insight into the impact of several independent organizational factors on the usage of supply chain management tools in Eastern European organizations. Among the considered factors, employee education has the strongest impact on the usage of 
supply chain management tools in Slovenia. Alternatively, in Croatia, employee position within the organization and the size of the organization are the most valuable factors to consider when assessing supply chain management tool usage.

Results from the survey lead us to conclude that changing the usage of management tools in Slovenia is possible, especially when employee education level is considered. Hence, we infer that as the level of employee education in a Slovenian organization increases, so does the usage of supply chain management tools. On the other hand, results for Croatian organizations are varied. The use of outsourcing is significantly associated with employee position and organization size. Mission and vision statements are associated with employee education and organization size. Lastly, knowledge management is associated with employee position. Noticeable is the lack of influence employee education has on Croatian organization tool usage compared to Slovenia. We conclude that in Croatian organizations employee education is not as influential but rather hierarchical position in an organization is more important regarding the usage of supply chain management tools.

Additionally, our results present a foundation for understanding the usage of supply chain management tools in new European countries (e.g. former transition countries). These results may assist managers in understanding prevalent management practices and behaviors. This is of paramount importance for organizations integrating with supply chain partners from that geographic area or foreign organizations considering expansion into these regions. Future research might also investigate tool usage by industry as supply chain management requirements often vary by industry and product. 
Limitations include that the study is restricted to selected organizational factors and the few - i.e. selected five most commonly used supply chain management tools. The outlined limitations present the most probable further research directions as the drastic differences in organizational factors and their influence on supply chain management tool usage in Slovenia and Croatia mean further research is needed to understand other factors that are more useful, especially in Croatia. Additionally, both Slovenia and Croatia are previous socialist countries. However, the socialist systems in these countries are different from those typically in other socialist countries, like Soviet Union and Poland. Generalizations of findings are thus limited to countries having similar social systems, due to the distinct country development paths within socialistic countries. While the Eastern European sample collected for this study provides interesting insights, future studies might expand the research to include other geographic regions. 


\section{Appendix}

\section{Figure 1: Model of factors that influence organization behavior}

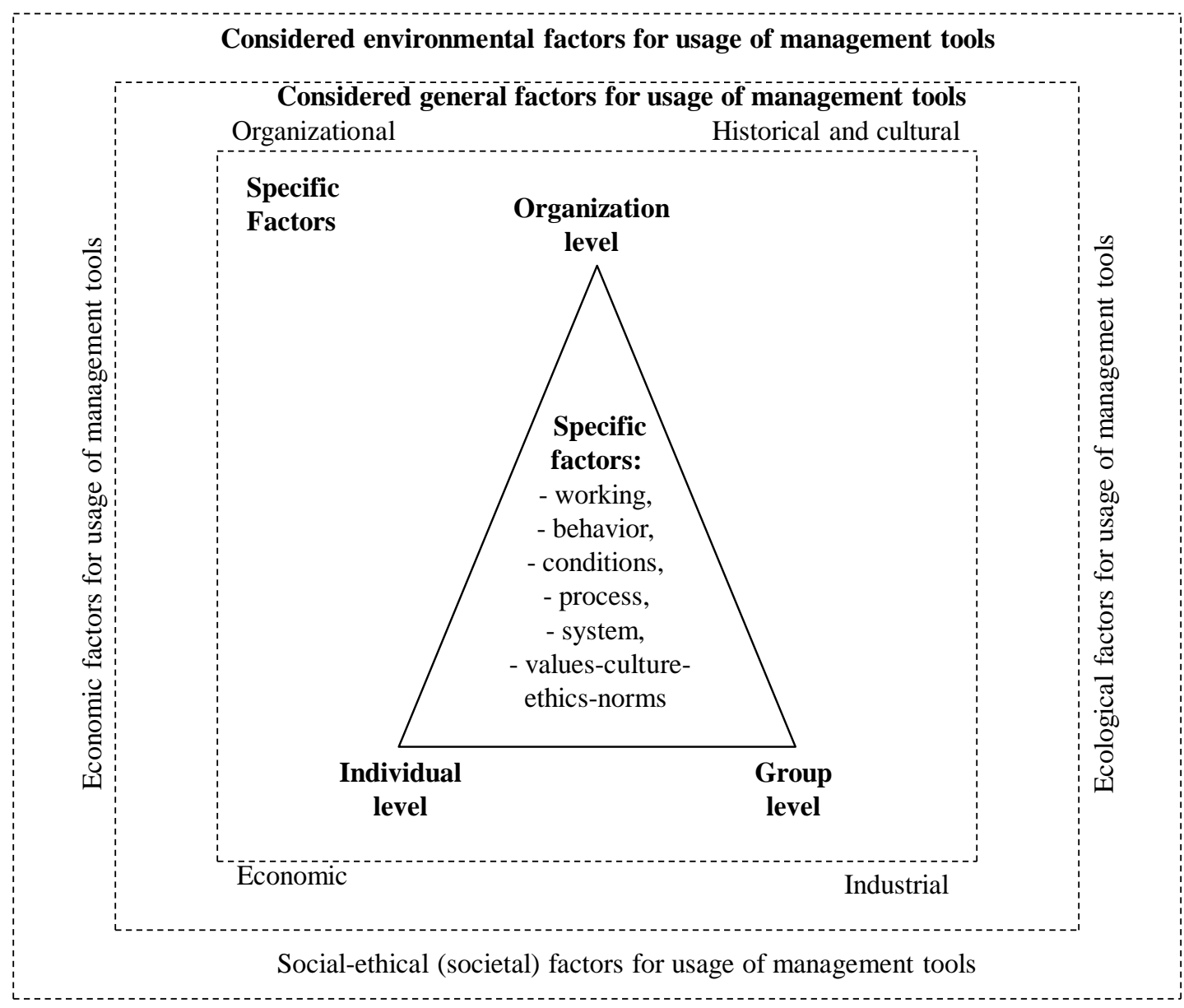




\section{Figure 2: Usage of management tools in Slovenia, Croatia, and Europe ${ }^{a}$}

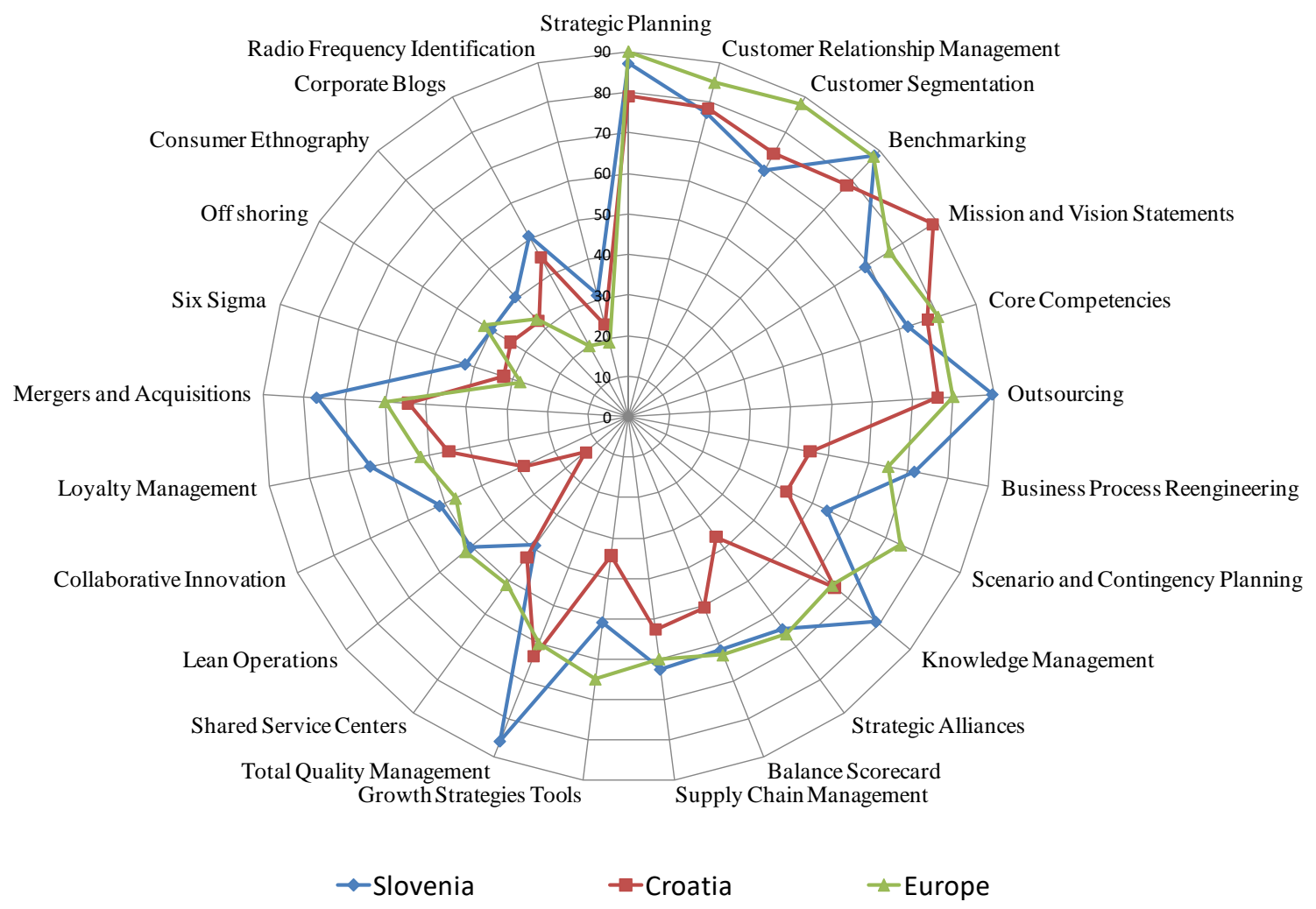

${ }^{\text {a }}$ Data for Slovenia and Croatia are original to this study research, while data for Europe were obtained from the Bain Management Tools and Trends 2007(Rigby and Bilodeau, 2007). 
Figure 3: The model used to predict the usage of management tools

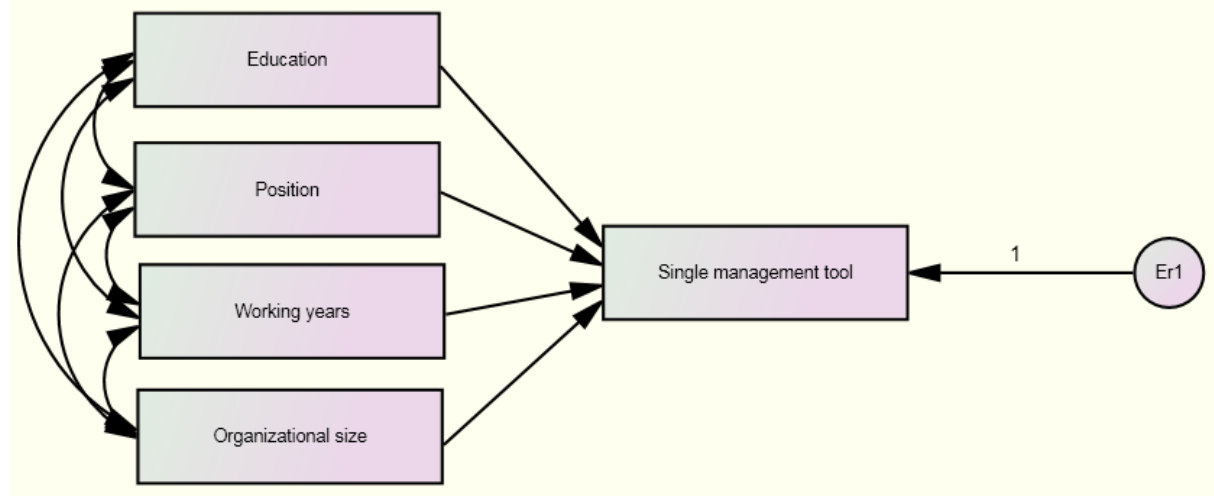




\section{Table 1: Top ten most commonly used supply chain management tools worldwide ${ }^{a}$}

\begin{tabular}{|l|l|l|l|l|l|}
\hline \multicolumn{1}{|c|}{ Region } & Global & $\begin{array}{l}\text { North } \\
\text { America }\end{array}$ & Europe & Croatia & Slovenia \\
\hline Strategic Planning & 1 & 1 & 1 & 8 & 8 \\
\hline $\begin{array}{l}\text { Customer Relationship } \\
\text { Management }\end{array}$ & 2 & 3 & 4 & 4 & 7 \\
\hline Customer Segmentation & 3 & 6 & $2(\mathrm{t})$ & 5 & 11 \\
\hline Benchmarking & 4 & 2 & $2(\mathrm{t})$ & 2 & 2 \\
\hline Core Competencies & $5(\mathrm{t})$ & 5 & $5(\mathrm{t})$ & 3 & 3 \\
\hline $\begin{array}{l}\text { Mission and Vision } \\
\text { Statements }\end{array}$ & $5(\mathrm{t})$ & 4 & 7 & 1 & 6 \\
\hline Outsourcing & 7 & 8 & $5(\mathrm{t})$ & 6 & 1 \\
\hline $\begin{array}{l}\text { Business Process } \\
\text { Reengineering }\end{array}$ & $8(\mathrm{t})$ & $10(\mathrm{t})$ & $10(\mathrm{t})$ & $10(\mathrm{t})$ & 10 \\
\hline Knowledge Management & $8(\mathrm{t})$ & 12 & $10(\mathrm{t})$ & 7 & 4 \\
\hline $\begin{array}{l}\text { Scenario and Contingency } \\
\text { Planning }\end{array}$ & $8(\mathrm{t})$ & 9 & 8 & $10(\mathrm{t})$ & 12 \\
\hline Strategic alliances & 11 & 7 & 9 & 20 & 17 \\
\hline Growth strategy tools & 14 & $10(t)$ & $10(t)$ & 19 & 18 \\
\hline Total quality management & 15 & $18(t)$ & $14(t)$ & 9 & 5 \\
\hline Balanced scorecard & 12 & $13(t)$ & 13 & 13 & 9 \\
\hline Supply chain management & 13 & $13(t)$ & $14(t)$ & 12 & 15 \\
\hline
\end{tabular}

${ }^{\text {a }}$ Data for Slovenia and Croatia are original to this study research, while data for regions, Global, North America, and Europe, are from the Bain Management Tools and Trends 2007(Rigby and Bilodeau, 2007). The shaded area represents the top ten most commonly used management tools from the 2007 Bain study. Tools which belong to the top ten most commonly used management tools in other considered geographic areas (italics).

(t) indicates a tie 


\section{Table 2: Employee Position}

\begin{tabular}{|l|r|r|r|r|}
\hline \multicolumn{1}{|c|}{ Employee Position } & \multicolumn{2}{c|}{ Slovenia } & \multicolumn{2}{c|}{ Croatia } \\
\hline & Frequency & Percent & Frequency & Percent \\
\hline Non-supervisory staff & 61 & $39.4 \%$ & 81 & $43.8 \%$ \\
\hline Low manager & 13 & $8.4 \%$ & 23 & $12.4 \%$ \\
\hline Middle & 48 & $31.0 \%$ & 45 & $24.3 \%$ \\
\hline Upper & 19 & $12.3 \%$ & 20 & $10.8 \%$ \\
\hline CEO member & 9 & $5.8 \%$ & 14 & $7.6 \%$ \\
\hline Subtotal & 150 & $96.8 \%$ & 183 & $98.9 \%$ \\
\hline Missing & 5 & $3.2 \%$ & 2 & $1.1 \%$ \\
\hline Total & 155 & $100.0 \%$ & 185 & $100.0 \%$ \\
\hline
\end{tabular}

Table 3: Organization Size

\begin{tabular}{|l|r|r|r|r|}
\hline \multicolumn{1}{|c|}{ Organization Size } & \multicolumn{2}{c|}{ Slovenia } & \multicolumn{2}{c|}{ Croatia } \\
\hline \# of employees & Frequency & Percent & Frequency & Percent \\
\hline Less than 10 & 21 & $13.5 \%$ & 13 & $7.0 \%$ \\
\hline 10 to 49 & 29 & $18.7 \%$ & 15 & $8.1 \%$ \\
\hline 50 to 249 & 68 & $43.9 \%$ & 44 & $23.8 \%$ \\
\hline More than 250 & 37 & $23.9 \%$ & 113 & $61.1 \%$ \\
\hline Total & 155 & $100.0 \%$ & 185 & $100.0 \%$ \\
\hline
\end{tabular}


Table 4: Demographic profile of the survey respondents from Slovenia and Croatia

\begin{tabular}{|l|l|l|}
\hline \multicolumn{1}{|c|}{ Gender } & Slovenia & Croatia \\
\hline Male & $48.4 \%$ & $48.1 \%$ \\
\hline Female & $51.6 \%$ & $51.9 \%$ \\
\hline Education Level & \multicolumn{2}{|c|}{} \\
\hline Secondary school & $4.2 \%$ & $9.2 \%$ \\
\hline Bachelor degree & $56.9 \%$ & $61.4 \%$ \\
\hline Master/PhD & $38.9 \%$ & $29.3 \%$ \\
\hline Type of Education & \multicolumn{2}{|l}{} \\
\hline Humanistic & $2.8 \%$ & $1.1 \%$ \\
\hline Social & $68.3 \%$ & $58.7 \%$ \\
\hline Natural \& Technical & $20.7 \%$ & $34.2 \%$ \\
\hline Other & $8.3 \%$ & $5.9 \%$ \\
\hline Position & \multicolumn{2}{|l}{} \\
\hline Specialists & $40.7 \%$ & $44.3 \%$ \\
\hline Low management & $8.7 \%$ & $12.6 \%$ \\
\hline Middle management & $32.0 \%$ & $24.6 \%$ \\
\hline Top management & $12.7 \%$ & $10.9 \%$ \\
\hline CEO & $6.0 \%$ & $7.7 \%$ \\
\hline
\end{tabular}

\begin{tabular}{|l|l|l|}
\hline \multicolumn{1}{|c|}{ Organization size } & Slovenia & \multicolumn{1}{c|}{ Croatia } \\
\hline Micro (<9) & $13.5 \%$ & $7.0 \%$ \\
\hline Small (10-49) & $18.7 \%$ & $8.1 \%$ \\
\hline Medium (50-249) & $43.9 \%$ & $23.8 \%$ \\
\hline Large (> 250) & $23.9 \%$ & $61.1 \%$ \\
\hline Department & \multicolumn{2}{|c|}{} \\
\hline $\begin{array}{l}\text { Research \& } \\
\text { Development }\end{array}$ & $3.2 \%$ & $17.0 \%$ \\
\hline Fundamental processes & $25.3 \%$ & $24.7 \%$ \\
\hline Accounting & $14.9 \%$ & $4.4 \%$ \\
\hline Marketing & $11.7 \%$ & $8.8 \%$ \\
\hline Board of directors & $29.2 \%$ & $37.4 \%$ \\
\hline Other & $15.6 \%$ & $7.7 \%$ \\
\hline Economy sector & \multicolumn{2}{|c|}{} \\
\hline Primary & $1.9 \%$ & $1.1 \%$ \\
\hline Secondary & $27.7 \%$ & $18.6 \%$ \\
\hline Tertiary & $43.2 \%$ & $71.6 \%$ \\
\hline Quaternary & $27.1 \%$ & $8.7 \%$ \\
\hline Mean (in years) & & 36.90 \\
\hline Age & 44.35 & 13.69 \\
\hline Work Experience & 20.49 & 9.56 \\
\hline Time with Organization & 9.03 \\
\hline
\end{tabular}


Table 5: Means, Standard Deviations, and Correlations

\begin{tabular}{|c|c|c|c|c|c|c|c|c|c|c|}
\hline Variable & M & $\mathrm{SD}$ & 1 & 2 & 3 & 4 & 5 & 6 & 7 & 8 \\
\hline Education & 2.3 & 0.58 & 1 & & & & & & & \\
\hline Position & 2.3 & 1.31 & $.137 *$ & 1 & & & & & & \\
\hline Working years & 17 & 8.8 & -0.038 & $.138 *$ & 1 & & & & & \\
\hline Organizational size & 3.1 & 0.98 & .046 & $-.277 * *$ & .029 & 1 & & & & \\
\hline Outsourcing & 1.7 & 0.75 & $-.241 * *$ & $-.178 * *$ & -.073 & .077 & 1 & & & \\
\hline $\begin{array}{l}\text { Knowledge } \\
\text { management }\end{array}$ & 1.9 & 0.81 & $-.156^{* *}$ & $-.121 *$ & -.032 & -.015 & $.268 * *$ & 1 & & \\
\hline $\begin{array}{l}\text { Total Quality } \\
\text { management }\end{array}$ & 1.9 & 0.77 & $-.285^{* *}$ & $-.218 * *$ & $-.109 *$ & .027 & $.293 * *$ & $.411 * *$ & 1 & \\
\hline $\begin{array}{l}\text { Mission and vision } \\
\text { statements }\end{array}$ & 1.7 & 0.78 & $-.196 * *$ & -.061 & .081 & $-.154 * *$ & $.284 * *$ & $.233 * *$ & $.256^{* *} *$ & 1 \\
\hline $\begin{array}{l}\text { Customer } \\
\text { segmentation }\end{array}$ & 2 & 0.78 & -.105 & $-.156^{* *}$ & .016 & -.021 & $.285^{* *}$ & $.193 * *$ & $.150 * *$ & $.362 * *$ \\
\hline
\end{tabular}

Note: $n=328-340$ due to the missing values. Data for both samples are presented together.

$* \mathrm{p}<0.05 ; * * \mathrm{p}<0.001$ 
Table 6: Standardized regression coefficients for management tool usage in Slovenia

\begin{tabular}{|c|c|c|c|c|c|c|}
\hline \multirow{6}{*}{$\begin{array}{l}. \frac{\pi}{\pi} \\
\frac{0}{\Delta} \\
\frac{0}{\sqrt{3}}\end{array}$} & Management Tool & Education & Position & $\begin{array}{l}\text { Working } \\
\text { Years }\end{array}$ & Organization Size & $\begin{array}{l}\text { Variance } \\
\text { Explained }\end{array}$ \\
\hline & Outsourcing & $-0.449 * *$ & ns & ns & ns & $24.9 \%$ \\
\hline & Knowledge Management & $-0.444 * *$ & ns & ns & $-0.167 *$ & $25.0 \%$ \\
\hline & Total Quality management & $-0.482 * *$ & $-0.211^{*}$ & ns & ns & $35.1 \%$ \\
\hline & $\begin{array}{l}\text { Mission and Vision } \\
\text { Statements }\end{array}$ & $-0.351 * *$ & ns & ns & ns & $15.0 \%$ \\
\hline & Customer Segmentation & $-0.362 * *$ & ns & ns & ns & $14.8 \%$ \\
\hline
\end{tabular}

$\mathrm{n}=135-138$ due to the missing values; outsourcing = 138; knowledge management = 135; total quality management $=138$; mission and vision statements $=138$; customer segmentation $=137$.

$* \mathrm{p}<.05$

$* * \mathrm{p}<.01$

Table 7: Standardized regression coefficients for management tool usage in Croatia

\begin{tabular}{|c|c|c|c|c|c|c|}
\hline \multirow{6}{*}{ 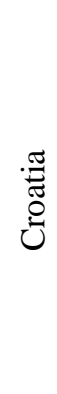 } & Management Tool & Education & Position & Working Years & Organization Size & $\begin{array}{l}\text { Variance } \\
\text { Explained }\end{array}$ \\
\hline & Outsourcing & $\mathrm{ns}$ & $-0.265^{*}$ & ns & $-0.187 *$ & $6.2 \%$ \\
\hline & Knowledge Management & ns & $-0.180^{*}$ & $\mathrm{~ns}$ & ns & $3.2 \%$ \\
\hline & Total Quality management & ns & ns & ns & ns & $2.3 \%$ \\
\hline & $\begin{array}{l}\text { Mission and Vision } \\
\text { Statements }\end{array}$ & $-0.161 *$ & ns & ns &.$-0.184 *$ & $7.1 \%$ \\
\hline & Customer Segmentation & $\mathrm{ns}$ & ns & ns & ns & $3.2 \%$ \\
\hline
\end{tabular}

$\mathrm{n}=177-179$ due to the missing values; outsourcing = 179; knowledge management = 178; total quality management $=177 ;$ mission and vision statements $=179 ;$ customer segmentation $=179$.

$* \mathrm{p}<.05$

$* * \mathrm{p}<.01$ 


\section{References}

Armstrong, M. (2006), A Handbook of Management Techniques: A comprehensive guide to achieving managerial excellence and improved decision making, Kogan Page, London.

Armstrong, J.S. and Overton, T.S. (1977), "Estimating nonresponse bias in mail surveys", Journal of Marketing Research, Vol. 14 No. 3, pp. 396-402.

Barney, J. (1991), "Firm resources and sustained competitive advantage", Journal of Management, Vol. 17 No. 1, pp. 99-120.

Barney, J., Wright, M. and Ketchen, D.J. (2001), "The resource-based view of the firm: Ten years after 1991", Journal of Management, Vol. 27 No. 6, pp. 625-41.

Barratt, M. (2004),"Understanding the meaning of collaboration in the supply chain", Supply Chain Management: An International Journal, Vol. 9 No. 1, pp. 30 - 42

Barthélemy, J. (2001), “The hidden costs of IT outsourcing”, Sloan Management Review, Vol. 42 No. 3, pp. 60-69.

Black, J. (1997), Dictionary of Economics, Oxford University Press, Oxford.

Bollinger, A.S. and Smith, R.D. (2001), "Managing organizational knowledge as a strategic asset", Journal of Knowledge Management, Vol. 5 No. 1, pp.8-18.

Brah, S.A. and Lim, H.Y. (2006), "The effects of technology and TQM on the performance of logistics companies", International Journal of Physical Distribution \& Logistics Management, Vol. 36 No. 3, pp.192-209.

Buchanan, F. and Huczynski, A. (2010), Organizational Behaviour, Pearson, Harlow.

Burgess, K., Singh, P.J., and Koroglu, R. (2006) "Supply chain management: a structured literature review and implications for future research", International Journal of Operations \& Production Management, Vol. 26 No 7, pp.703 - 729

Certo, S. and Certo, T. (2009), Modern Management: Concepts and Skills, Pearson, Harlow. 
Chandler, A. (1996), Strategy and Structure: Chapters in the History of the American Industrial Enterprise, MIT Press, Cambridge, MA.

Chorn, N.H. (1991), “Total quality management: panacea or pitfall?”, International Journal of Physical Distribution \& Logistics Management, Vol. 21 No. 8, pp. 31-35.

Cole, G. (2004), Management Theory and Practice, Thomson, London.

Cooper, C. and Argyris, C. (1998), The Concise Blackwell Encyclopedia of Management, Blackwell, Malden, MA.

Crainer, S. (2004), Financial Times Handbook of Management: The State of the Art, Pearson, Harlow.

Daft, R. (1983), Organization Theory and Design, Western Pub, New York, NY.

Daft, R. (2005), Management, South-Western College, Cincinnati, OH.

Daft, R. (2007), Organization Theory and Design, South-Western College, Cincinnati, OH.

Daft, R. (2009), The New Era of Management, South-Western College, Cincinnati, OH.

Ellram, L.M. and Cooper, M.C. (1990),"Supply chain management, partnership, and the shipper third party relationship", The International Journal of Logistics Management, Vol. 1 No. 2, pp. 1-10.

Etzioni, A. (1997), Modern Organizations, Prentice-Hall, New York, NY.

Fawcett, S.E. and Magnan, G.M. (2002), "The rhetoric and reality of supply chain integration", International Journal of Physical Distribution \& Logistics Management, Vol. 32 No. 5, pp. 339-361.

Filbeck, G., Raymond, G., Greenlee, T. and Speh, T. (2005), "The stock price reaction to supply chain management advertisements and company value", Journal of Business Logistics, Vol. 26 No. 1, pp. 199-216. 
Galbraith, J. (2002), Designing Organizations, Wiley, New York, NY.

Gove, P. (2002), Webster's Third New International Dictionary, Merriam Webster, Springfield, MA.

Hartley, R. (2007), Management Mistakes and Successes, John Wiley \& Sons, New York, NY.

Hatch, M. (2006), Organization Theory: Modern, symbolic, and postmodern perspectives, Oxford University Press, Oxford.

Hitt, M., Black, S. and Porter, L. (2008), Management, Prentice Hall, New York, NY.

Ho, R. (2006), Handbook of Univariate and Multivariate Data Analysis and Interpretation with SPSS, Chapman \& Hall/CRC, Boca Raton, FL.

Jennings, M. (2005), Business: Its Legal, Ethical and Global Environment, South-Western Pub, Brentford.

Lacity, M. and Hirschheim, R. (1993), Information Systems Outsourcing, Wiley, New York, NY.

Lafley, A. and Johnson, M. (2010), Seizing the White Space: Business Model Innovation for Growth and Renewal, Harvard Business Press, Boston, MA.

Leech, L., Barrett, C. and Morgan, A. (2008), SPSS for Intermediate Statistics, Taylor \& Francis Group, New York, NY.

Linstead, S., Fulop, L. and Lilley, S. (2009), Management \& Organization: A critical text, Palgrave - MacMillan, New York, NY.

Lipton, M (1996), "Demystifying the development of organizational vision”, Sloan Management Review, Vol. 37 No. 4, pp. 83-92.

Lock, D. (1992), Handbook of Management, Gower Publishing, Burlington, Vermont.

Martin, R. (2009), Opposable Mind: Winning Through Integrative Thinking. Harvard Business Press, Boston, MA. 
McAuley, J., Duberley, J. and Johnson, P. (2007), Organization Theory: Challenges and Perspectives, Pearson, Harlow.

Mullins, L. (2010), Management and Organisational Behaviour, Prentice Hall, New York, NY.

Pascale, R. (1990), Managing on the Edge, Simon \& Shuster, New York, NY.

Power, D. (2005), "Supply chain management integration and implementation: a literature review", Supply Chain Management: An International Journal, Vol. 10 No. 4, pp. 252263.

Potocan, V. and Kuralt, B. (2007), "Synergy in Business", The Journal of Academy of Business, Vol. 12 No. 1, pp. 199-204.

Potocan, V. and Mulej, M. (2009), "How to improve innovativeness of small and medium enterprises", Management, Vol. 14 No. 1, pp. 1-20.

Potocan, V. and Nedelko, Z. (2010), "Personal values of members in Slovenian organizations (In Slovene)", working paper, Faculty of Economics and Business, University of Maribor, Maribor.

Potocan, V. and Dabic, M. (2011), "Management tools (In Slovene)", working paper, Faculty of Economics and Business, University of Maribor, Maribor.

Quélin, B. and Duhamel, F. (2003), "Bringing together strategic outsourcing and corporate strategy: Outsourcing motives and risks", European Management Journal, Vol. 21 No. 5, pp. 647-661.

Quick, D. and Nelson, J. (2009), Principles of Organization Behavior: Realities and Challenges, South-Western College, Cincinnati, OH.

Richey, R.G., Tokman, M., Wright, R.E., and Harvey, M.G. (2005), “Monitoring reverse logistics programs: A roadmap to sustainab le development in emerging markets", Multinational Business Review, Vol. 13 No. 3, pp. 41- 65. 
Rigby, D. (2001), “Situational strategies: A management tool for turbulent times”, Strategy \& Leadership, Vol. 29 No. 6, pp. 8-12.

Rigby, D. and Bilodeau, B. (2007), “Management tools and trends 2007”, available at: http://www.bain.com/bainweb/PDFs/cms/Marketing/Management\%20Tools\%202007\%20 BB.pdf (accessed 12 April 2011).

Rigby, D. and Bilodeau, B. (2009), “Management tools and trends 2009”, available at: http://www.bain.com/bainweb/PDFs/cms/Public/Management_Tools_2009.pdf (accessed 12 April 2011).

Rigby, D. (2011), “Management tools”, available at: http://www.bain.com/management_tools/home.asp (accessed 12 April 2011).

Rogelberg, S.G. and Stanton, J. M. (2007), "Introduction: Understanding and dealing with organizational survey nonresponse", Organization Research Methods, Vol. 10 No. 2 pp. 195-209.

Schermerhorn, J. and Chappell, D. (2004), Core Concepts of Management, Wiley, New York, NY.

Schermerhorn, J. (2009), Introduction to Management, Wiley, New York, NY.

Slone, R. E., Mentzer, J. T., and Dittmann, J.P. (2007) “Are you the weakest link in your company’s supply chain?”, Harvard Business Review, Vol. 84 No. 9 pp. 116.

Wren, D. (2004), The History of Management Thought, Wiley, New York, NY.

Zineldin, M. (2004), “Total relationship and logistics management", International Journal of Physical Distribution \& Logistics Management, Vol. 34 No. 3/4, pp. 286-301. 